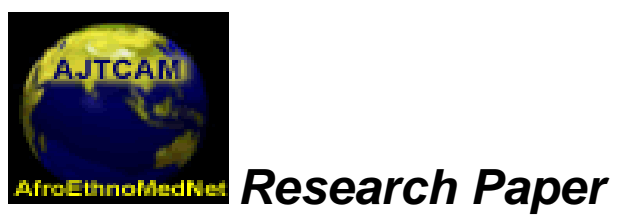

Afr. J. Traditional,
Complementary and
Alternative Medicines

www.africanethnomedicines.net

ISSN 0189-6016@2008

\title{
ANTIMICROBIAL ACTIVITY OF ESSENTIAL OILS OF OCIMUM GRATISSIMUM L. FROM DIFFERENT POPULATIONS OF KENYA
}

\section{Lexa G. Matasyoh ${ }^{\mathrm{a}, *}$, Josphat C. Matasyoh ${ }^{\mathrm{b}}$, Francis N. Wachira ${ }^{\mathrm{c}}$, Miriam G. Kinyua ${ }^{\mathrm{d}}$, Anne W. Thairu Muigai ${ }^{a}$ and Titus K. Mukiama ${ }^{e}$}

${ }^{\mathrm{a} D e p a r t m e n t ~ o f ~ B o t a n y, ~ J o m o ~ K e n y a t t a ~ U n i v e r s i t y ~ o f ~ A g r i c u l t u r e ~ a n d ~ T e c h n o l o g y, ~ P . O . ~ B o x ~ 62000, ~}$ Nairobi, Kenya.

${ }^{b}$ Department of Chemistry, Egerton University, P.O. Box 536, Njoro, Nakuru, Rift Valley, Kenya.

${ }^{c}$ Department of Biochemistry, Egerton University, P.O. Box 536, Njoro, Nakuru, Rift Valley, Kenya.

${ }^{\mathrm{d}}$ Kenya Agricultural Research Institute, P.O. Njoro, Nakuru, Kenya.

${ }^{\mathrm{e}}$ Department of Botany, Nairobi University, P.O. Box 29053, Nairobi, Kenya.

*E-mail: lexa111@,hotmail.com

\begin{abstract}
Hydro-distilled volatile oils from the leaves of Ocimum gratissimum L. (Lamiaceae) of 13 populations of different silvicultural zones were evaluated for antimicrobial activity against Gram positive (Staphylococcus aereus, Bacillus spp.) and Gram negative (Escherichia coli, Pseudomonas aeruginosa, Samonella typhi, Klebisiella pneumoniae, Proteus mirabilis) bacteria and a pathogenic fungus, Candida albicans. All the essential oils are active to the tested microbiles with different strength. The highest antimicrobial activity against Gram positive bacteria (Staphylococcus aureus) and Gram negative bacteria (Pseudomonas aeruginosae and Proteus mirabilis) was observed from the eastern Kenya (Meru) oil. Meru oil was the best and its effectiveness was consistent on nearly all the microbes tested. The oil from the plant growing in the coastal region of Kenya (Mombasa) showed the best effect only on Gram negative bacteria (Escherichia coli and Proteus mirabilis). Both oils (Meru and Mombasa) were dominated by monoterpenes accounting for $92.48 \%$ and $81.37 \%$ respectively. The monoterpene fraction was characterized by a high percentage of eugenol (68.8\%) for Meru oil and $74.10 \%$ for Mombasa oil. The other major monoterpene was methyl eugenol (13.21\%). Camphor (0.95\%) was observed only in the Meru oil. (Cis)-Ocimene, (trans)-ocimene and $\beta$-pinene were present in both Meru and Mombasa oils. The sesquiterpenes present in fairly good amounts in both oils were germacrene $\mathrm{D}$ and (trans)-caryophyllene. The minor sesquiterpenes were $\alpha$ farnesene $(0.85 \%)$ and $\beta$-bisabolene $(0.74 \%)$ which were present in the Meru oil only.
\end{abstract}

Key words: Antimicrobial activity, Ocimum gratissimum L., Eugenol, Essential oil

\section{Introduction}

Ocimum gratissimum L. (Lamiaceae) is an important herbal medicinal plant not only in Kenyan communities but also in the sub-Saharan Africa. The leaves are rubbed between the palms and sniffed as remedy for blocked nostrils (Kokwaro, 1993) and also used for abdominal pains, sore eyes, ear infections, coughs, barrenness, fever, convulsions, and tooth gargle, regulation of menstruation and prolapse of the rectum (Watt and BreyerBrandwijk, 1962; Harjula, 1980; FAO, 1986 and Kokwaro, 1993).

Several species and varieties of plants belonging to the genus Ocimum have been reported to yield oil of diverse nature, commonly known as basilica oils. Lemos et al., (2005), Adebolu et al. (2005) and Matasyoh et al., (2007) reported some chemical compounds and active ingredients from these plants such as eugenol, linalol, methyl cinnamate, camphor and thymol. Various species of Ocimum have been reported for their numerous medical uses (Mshana et al., 2000). 
The present work reports the antimicrobial activity of the essential oil of Ocimum gratissimum L., and the chemical composition of the essential oils of the most active antimicrobial populations growing in different parts of Kenya.

\section{Materials and Methods Plant material}

The leaves of O. gratissimum L. were collected from wild populations during the pre flowering season in August, 2005 from 13 districts of Kenya. Voucher specimens (voucher No. 805LG) were deposited at the Department of Botany, Egerton University.

\section{Essential oil distillation}

Fresh leaves were subjected to hydro-distillation in a modified Clevenger-type apparatus for at least $4 \mathrm{hrs}$ according to the British pharmacopoeia. The essential oil (EO) was obtained in a yield of $w / w$ after drying over anhydrous sodium sulphate $\left(\mathrm{Na}_{2} \mathrm{SO}_{4}\right)$. The oil was stored in a sealed glass vial (Bijoux bottle) at $4{ }^{\circ} \mathrm{C}$.

\section{Antimicrobial screening}

The micro-organisms used were Staphylococcus aureus ATCC25923, Pseudomonas aeruginosaea ATCC 27853, Escherichia coli ATCC 25922 and clinical isolates: Salmonella typhi, Klebsiella pneumoniae, Proteus mirabilis, Bacillus spp. and Candida albicans. The agar disc diffusion method was employed for the screening of antimicrobial activities of the EO according to the National Committee of Clinical Laboratory Standards (NCCLS, 1999). The test was performed in sterile Petri-dishes (90 mm diameter) containing solid and sterile Mueller-Hinton agar (MHA) medium for the growth of bacteria and Sabouraud dextrose agar (SDA) for the growth of fungi. The oils absorbed on sterile paper discs $(10 \mu 1$ per Whatman disc of $6 \mathrm{~mm}$ diameter) were placed on the surface of the media previously inoculated with $0.1 \mathrm{ml}$ of microbial suspension $(1 \mu \mathrm{g}$ per Petri-dish). The microbial suspension, freshly grown in Nutrient Broth was standardized to a cell density of $1.5 \times 10^{8}$ (Mc Farland No. 0.5). The positive antibacterial and antifungal activities were established by the presence of measurable zones of inhibition after $24 \mathrm{hrs}$ of incubation at $37^{\circ} \mathrm{C}$. Chloramphenical and Nystatin were used as antibiotic and antifungal references respectively. All tests were performed in duplicate.

\section{GC, GC-MS Analysis}

Gas chromatographic (GC), and GC-Mass spectrometry (MS) was carried out on Mombasa and Meru oils only. Gas chromatographic (GC) analyses of essential oils diluted in methyl tert-butyl ether (MTBE) were performed on an Agilent GC-MSD apparatus equipped with an Rtx-5SIL MS ('Restek') (30 m x0.25 mm i.d., 0.25 $\mu \mathrm{m}$ film thickness) fused-silica capillary column. Helium (at $0.8 \mathrm{ml} / \mathrm{min}$ ) was used as a carrier gas. Samples were injected in the split mode at a ratio of $1: 10-1: 100$. The injector was kept at $250{ }^{\circ} \mathrm{C}$ and the transfer line at $280{ }^{\circ} \mathrm{C}$. The column was maintained at $50{ }^{\circ} \mathrm{C}$ for $2 \mathrm{~min}$ and then programmed to $260{ }^{\circ} \mathrm{C}$ at $5{ }^{\circ} \mathrm{C} / \mathrm{min}$ and held for $10 \mathrm{~min}$ at $260{ }^{\circ} \mathrm{C}$. The MS was operated in the EI mode at $70 \mathrm{eV}$, in $\mathrm{m} / \mathrm{z}$ range $42-350$. The identification of the compounds was performed by comparing their retention indices and mass spectra with those reported (Adams, 1995) and supplemented by Wiley and Quadlib 1607 GC-MS libraries.

\section{Minimum inhibitory concentration (MIC)}

Serial dilutions of the EO were done using $10 \%$ TWEEN 80 in distilled sterile water. Water was used as a control. The MIC was considered the lowest concentration of the sample that no visible growth was observed. Visible growth (the positive antibacterial and antifungal activities) was established by the presence of measurable zones of inhibition after $24 \mathrm{hrs}$ of incubation at $37^{\circ} \mathrm{C}$.

\section{Results \\ Essential oil distillation}

The percentage yields $(\mathrm{w} / \mathrm{w})$ of the EOs obtained from the 13 populations is shown in Table 1 
Table 1: Yields of essential oil from Ocimum gratissimum L.

\begin{tabular}{|l|l|l|}
\hline \multicolumn{2}{|l|}{ Population } & \% yield weight/weight \\
\hline 1 & Njoro I & 0.78 \\
\hline 2 & Njoro II & 0.12 \\
\hline 3 & Mill House II & 0.79 \\
\hline 4 & Kericho & 0.21 \\
\hline 5 & Mill House I & 0.83 \\
\hline 6 & Kabarnet & 0.16 \\
\hline 7 & Meru & 0.49 \\
\hline 8 & Kakamega & 0.40 \\
\hline 9 & Thika & 0.52 \\
\hline 10 & Taita taveta & 0.74 \\
\hline 11 & Mombasa & 1.40 \\
\hline 12 & Kisumu & 1.24 \\
\hline 13 & Nyeri & 0.40 \\
\hline
\end{tabular}

\section{Antimicrobial activity}

The EOs were evaluated for antimicrobial activity against pathogenic strains of Gram positive (Staphylococcus aereus, Bacillus spp.) and Gram negative (Escherichia coli, Pseudomonas aeruginosa, Samonella typhi, Klebisiella pneumoniae, Proteus mirabilis) bacteria and a pathogenic fungus Candida albicans. The EOs are active against all the bacterial strains (Table 2) but the effectiveness of the oils is different from one population to another (Table 3). The reference antibiotic showed no activity in the three Gram negative bacteria among the five tested. It showed significant activity only on E. coli and K. pneumoniae (Table 2).

The EOs showed significant activity on all the Gram negative bacteria including those (Pseudomonas aeruginosa, Samonella typhi, and Proteus mirabilis) with resistance to reference antibiotic.

\section{Chemical composition of the essential oils}

As shown in Table 4, constituents in the sample from Eastern Kenya (Meru) and the coastal region of Kenya (Mombasa) were identified by GC-MS analysis. The oil was dominated by eugenol, which accounted for $68.81 \%$ (Meru) and $74.10 \%$ (Mombasa) respectively. Methyl eugenol (13.21\%) was found only in the sample from Meru.

\section{Minimum inhibitory concentration (MIC)}

The minimum inhibition concentration tested on the Eastern Kenya oil (Meru) showed that dilution of the EO affected its activity on some microbes (Matasyoh et al., 2007). That is, the activity of the oil varied with its concentration and kind of bacteria being treated. There was also a marked antifungal activity against Candida albicans. This antifungal activity seems not to be affected by the dilution of the oil. Among the Gram negative bacteria, the oil was very active against $E$. coli. The activity response to $E$. coli was more or less the same at (75 $\times 10^{2} \mu \mathrm{g}$ ) as that of chloramphenicol $(30 \mu \mathrm{g})$. The minimum inhibition concentration (MIC) for the oil was greater than that of reference antibiotic.

The MIC of oil ranged from 107 to $750 \mathrm{mg} / \mathrm{ml}$ for Gram negative bacteria and 93.7 to $150 \mathrm{mg} / \mathrm{ml}$ for Gram positive bacteria. The MIC of oil for the fungus C. albicans was $50 \mathrm{mg} / \mathrm{ml}$. The MIC of chloramphenical ranged from 22.5 to $31.3 \mathrm{mg} / \mathrm{ml}$ for both Gram negative and Gram positive microbes.

\section{Discussion}

The EO percentage yield of leaves from different population ranged from $0.16-1.40 \%$ weight/weight $(\mathrm{w} / \mathrm{w})$ Table 1. It was observed that the thicker and more velvet the leaves felt, the less percentage oil yield. 
Table 2: Antimicrobial activity of the essential oil of Ocimum gratissimum L. from 13 different ecological zones (populations) of Kenya

\begin{tabular}{|c|c|c|c|c|c|c|c|c|c|c|c|c|c|c|}
\hline $\begin{array}{l}\text { Micro } \\
\text { organism }\end{array}$ & \multicolumn{14}{|c|}{ INHIBITION ZONE } \\
\hline & $\mathbf{A}$ & $\mathbf{B}$ & $\mathbf{C}$ & $\mathbf{D}$ & $\mathbf{E}$ & $\mathbf{F}$ & $\mathbf{G}$ & $\mathbf{H}$ & I & $\mathbf{J}$ & $\mathbf{K}$ & $\mathbf{L}$ & $\mathbf{M}$ & $\mathbf{N}$ \\
\hline \multicolumn{15}{|l|}{$\begin{array}{l}\text { Gram } \\
\text { positive }\end{array}$} \\
\hline $\begin{array}{l}\text { Staphylococc } \\
\text { us aureus } \\
\text { ATCC } 25923\end{array}$ & $20.0 \pm 0$ & $20.0 \pm 0$ & $13.5 \pm 0.7$ & $20.0 \pm 0$ & $15.0 \pm 0$ & $21.0 \pm 1.4$ & $26.6 \pm 5.7$ & $22.0 \pm 4.0$ & $25.3 \pm 1.2$ & $19.3 \pm 1.2$ & $25.3 \pm 4.6$ & $15.0 \pm 1.4$ & $15.0 \pm 1.4$ & $24.5 \pm 0.7$ \\
\hline $\begin{array}{l}\text { Bacillus spp. } \\
\text { (Clinical } \\
\text { isolate) }\end{array}$ & $21.0 \pm 1.4$ & $20.5 \pm 0.7$ & $16.0 \pm 1.4$ & $22.0 \pm 0$ & $16.5 \pm 0.7$ & $25.0 \pm 1.4$ & $22.3 \pm 1.5$ & $17.3 \pm 2.5$ & $21.7 \pm 1.5$ & $16.7 \pm 1.2$ & $21.7 \pm 1.5$ & $18.3 \pm 2.5$ & $19.0 \pm 1.7$ & $30.0 \pm 0$ \\
\hline \multicolumn{15}{|l|}{$\begin{array}{l}\text { Gram } \\
\text { negative }\end{array}$} \\
\hline $\begin{array}{l}\text { Escherichia } \\
\text { coli } \\
\text { ATCC } 25922\end{array}$ & $14.0 \pm 0$ & $14.0 \pm 0$ & $10.5 \pm 0.7$ & $18.5 \pm 0.7$ & $10.5 \pm 0.7$ & $18.5 \pm 0.7$ & $21.7 \pm 2.1$ & $14.3 \pm 0.6$ & $21.7 \pm 5.0$ & $16.3 \pm 4.9$ & $19.3 \pm 3.8$ & $24.0 \pm 0$ & $25.0 \pm 1.4$ & $32.5 \pm 2.5$ \\
\hline $\begin{array}{l}\text { Pseudomonas } \\
\text { aeruginosae } \\
\text { ATCC } 27853\end{array}$ & $\mathrm{R}$ & $8.0 \pm 0$ & $\mathrm{R}$ & $7.5 \pm 0.7$ & $\mathrm{R}$ & $8.0 \pm 1.4$ & $9.0 \pm 2.6$ & $9.0 \pm 0$ & $8.0 \pm 1.7$ & $7.0 \pm 0$ & $9.3 \pm 3.2$ & $7.6 \pm 0.6$ & $7.3 \pm 0.6$ & $\mathrm{R}$ \\
\hline $\begin{array}{l}\text { Klebsiella } \\
\text { pneumoniae } \\
\text { (Clinical } \\
\text { isolate) }\end{array}$ & $12.0 \pm 0$ & $11.5 \pm 0.7$ & $9.0 \pm 1.4$ & $13.5 \pm 0.7$ & $9.0 \pm 1.4$ & $14.5 \pm 2.1$ & $18.0 \pm 2.8$ & $12.0 \pm 1.4$ & $15.5 \pm 0.7$ & $13.5 \pm 2.1$ & $25.0 \pm 4.2$ & $14.0 \pm 3.5$ & $15.0 \pm 2.6$ & $27.3 \pm 1.2$ \\
\hline $\begin{array}{l}\text { Proteus } \\
\text { mirabilis } \\
\text { (Clinical } \\
\text { isolate) }\end{array}$ & $11.5 \pm 0.7$ & $11.5 \pm 0.7$ & $8.0 \pm 0$ & $15.0 \pm 0$ & $8.5 \pm 0.7$ & $16.0 \pm 2.8$ & $16.0 \pm 1.7$ & $11.3 \pm 0.6$ & $12.7 \pm 2.1$ & $10.3 \pm 1.2$ & $13.0 \pm 1.7$ & $13.3 \pm 1.2$ & $15.3 \pm 2.5$ & $\mathrm{R}$ \\
\hline $\begin{array}{l}\text { Salmonella } \\
\text { typhi } \\
\text { (Clinical } \\
\text { isolate) } \\
\end{array}$ & $13.5 \pm 0.7$ & $13.5 \pm 0.7$ & $10.5 \pm 0.7$ & $18.0 \pm 2.8$ & $10.0 \pm 0$ & $18.5 \pm 2.1$ & $20.5 \pm 0.7$ & $13.5 \pm 0.7$ & $17.5 \pm 0.7$ & $10.5 \pm 0.7$ & $18.5 \pm 0.7$ & $20.0 \pm 1.7$ & $18.6 \pm 2.3$ & $\mathrm{R}$ \\
\hline \multicolumn{15}{|l|}{ Fungi } \\
\hline $\begin{array}{l}\text { Candida } \\
\text { albicans } \\
\text { (Clinical } \\
\text { isolate) }\end{array}$ & $*$ & $*$ & $*$ & $*$ & $*$ & $*$ & $*$ & $*$ & $*$ & $*$ & $*$ & $*$ & $*$ & $\mathrm{R}$ \\
\hline
\end{tabular}

Key: A=Njoro I; $\mathrm{B}=$ Njoro II; $\mathrm{C}=$ Mill House II; $\mathrm{D}=$ Kericho; $\mathrm{E}=$ Mill House I; F=Kabarnet; $\mathrm{G}=$ Meru; H=Nyeri; I=Kisumu; J=Kakamega; $\mathrm{K}=$ Thika; $\mathrm{L}=$ Taita taveta; $\mathrm{M}=$ Mombasa; $\mathrm{N}=$ Chloramphenical $*$ The organism was highly susceptible to the plant extract. MIC to be done. Clinical isolate from Kenya Medical Research Institute (KEMRI). 
Table 3: Variation in anti microbial activity among locally collected populations of O. gratissimum L. in Kenya

\begin{tabular}{|c|c|c|c|c|c|c|c|}
\hline \multirow[b]{2}{*}{ Population } & \multicolumn{7}{|c|}{ Inhibition Zone (mm) } \\
\hline & $\begin{array}{l}\text { E. coli } \\
\text { (Gram-ve) }\end{array}$ & $\begin{array}{l}\text { K. pneumoniae } \\
\text { (Gram -ve) }\end{array}$ & $\begin{array}{l}\text { S.typhi } \\
\text { (Gram -ve) }\end{array}$ & $\begin{array}{l}\text { P. aeruginosae } \\
\text { (Gram -ve) }\end{array}$ & $\begin{array}{l}\text { P. mirabilis } \\
\text { (Gram - ve) }\end{array}$ & $\begin{array}{l}\text { S. aureus } \\
\text { (Gram +ve) }\end{array}$ & $\begin{array}{l}\text { Bacillus spp } \\
\text { (Gram +ve) }\end{array}$ \\
\hline Chloramphenical & $32.50 \mathrm{a} *$ & $28.00 \mathrm{a}$ & $6.00 \mathrm{~h}$ & $6.00 \mathrm{c}$ & $6.00 \mathrm{f}$ & $24.50 \mathrm{a}$ & $30.00 \mathrm{a}$ \\
\hline Kabarnet & $18.50 \mathrm{cb}$ & $14.50 \mathrm{cb}$ & $18.50 \mathrm{bdc}$ & $8.00 \mathrm{bac}$ & $16.00 \mathrm{a}$ & $21.00 \mathrm{ba}$ & $25.00 \mathrm{~b}$ \\
\hline Kisumu & $21.00 \mathrm{cb}$ & $15.50 \mathrm{cb}$ & $17.50 \mathrm{ed}$ & $8.50 \mathrm{bac}$ & $13.00 \mathrm{bac}$ & $25.00 \mathrm{a}$ & $22.50 \mathrm{cb}$ \\
\hline Thika & $18.50 \mathrm{cb}$ & $25.00 \mathrm{a}$ & $18.50 \mathrm{bdc}$ & $10.50 \mathrm{a}$ & $13.50 \mathrm{bac}$ & $24.00 \mathrm{a}$ & $22.50 \mathrm{cb}$ \\
\hline Meru & $22.00 \mathrm{~b}$ & $18.00 \mathrm{~b}$ & $20.50 \mathrm{ba}$ & $10.00 \mathrm{ba}$ & $16.50 \mathrm{a}$ & $25.00 \mathrm{a}$ & $22.50 \mathrm{cb}$ \\
\hline Kericho & $18.50 \mathrm{cb}$ & $13.50 \mathrm{cbd}$ & $18.00 \mathrm{dc}$ & $7.50 \mathrm{bac}$ & $15.00 \mathrm{ba}$ & $20.00 \mathrm{bac}$ & $22.00 \mathrm{cb}$ \\
\hline Njoro I & $14.00 \mathrm{~cd}$ & $12.00 \mathrm{~cd}$ & $13.50 \mathrm{f}$ & $6.00 \mathrm{c}$ & $11.50 \mathrm{bcde}$ & $20.00 \mathrm{bac}$ & $21.00 \mathrm{~cd}$ \\
\hline Njoro II & $14.00 \mathrm{~cd}$ & $11.50 \mathrm{~cd}$ & $13.50 \mathrm{f}$ & $8.00 \mathrm{bac}$ & $11.50 \mathrm{bcde}$ & $20.00 \mathrm{bac}$ & $20.50 \mathrm{~cd}$ \\
\hline Mombasa & $25.00 \mathrm{~b}$ & $16.00 \mathrm{cb}$ & $20.00 \mathrm{bac}$ & $8.00 \mathrm{bac}$ & $16.50 \mathrm{a}$ & $15.00 \mathrm{bc}$ & $19.50 \mathrm{cde}$ \\
\hline Taita taveta & $24.00 \mathrm{~b}$ & $15.00 \mathrm{cb}$ & $21.00 \mathrm{a}$ & $8.00 \mathrm{bac}$ & $13.00 \mathrm{bac}$ & $15.00 \mathrm{bc}$ & $19.50 \mathrm{cde}$ \\
\hline Nyeri & $14.00 \mathrm{~cd}$ & $12.00 \mathrm{~cd}$ & $13.50 \mathrm{f}$ & $7.50 \mathrm{bac}$ & $11.50 \mathrm{bcde}$ & $22.00 \mathrm{ab}$ & $18.50 \mathrm{fde}$ \\
\hline Kakamega & $18.00 \mathrm{cb}$ & $13.5 \mathrm{cbd}$ & $10.50 \mathrm{~g}$ & $6.50 \mathrm{bc}$ & $11.00 \mathrm{cde}$ & $19.00 \mathrm{bac}$ & $17.00 \mathrm{fe}$ \\
\hline
\end{tabular}

*Values in the same column (inhibition zone in $\mathrm{mm}$ ) followed by the same letter do not differ significantly based on Duncan's multiple Range test (P<0.05) 
Table 4: Chemical composition of Ocimum gratissimum L. leaf oil

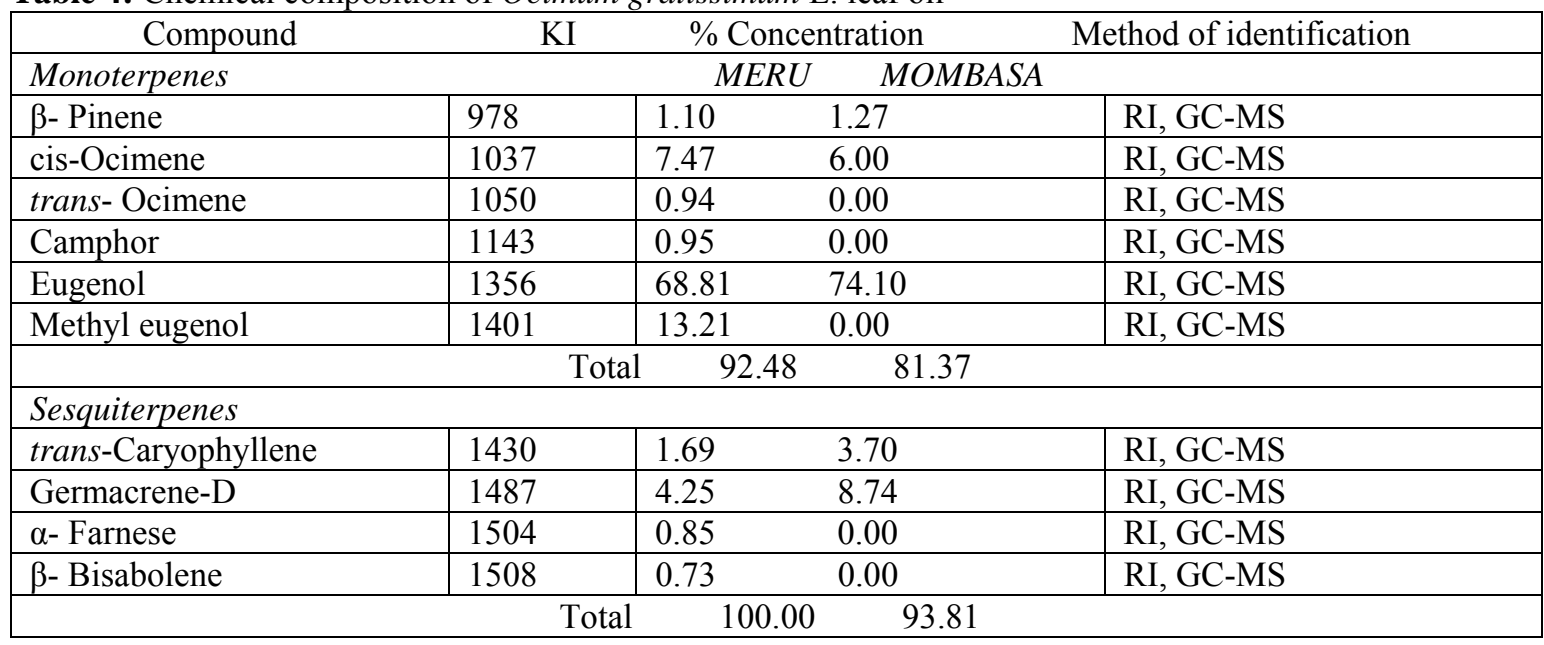

KI - Kovat index

The essential oils from 13 populations of Kenya were found to be active against all the bacteria strains including Gram positive (Staphylococcus aureus and Bacillus spp.) and Gram negative (Escherichia coli, Pseudomonas aeruginosae, Salmonella typhi, Klebsiella pneumoniae and Proteus mirabilis) bacteria (Tables 2 and 3). It also showed a marked antifungal activity against Candida albicans. The essential oils were more effective on all the microbes tested simlar to chloramphenical (Table 2), which showed resistance to the Gram negative bacteria (Pseudomonas aeruginosae, Proteus mirabilis and Salmonella typhi). It was also observed that the oils from some populations were more effective on some microbes than from the others. For instance, Meru oil and Thika oil showed greater inhibition zones on Staphylococcus aureus than those from the other populations (Table 2). Similarly, Kabarnet EO was more effective against Bacillus spp than the oils of the other remaining populations (Tables 2 and 3). Meru, Taita Taveta and Mombasa oils presented good activity against Gram negative bacteria (Escherichia coli and Salmonella typhi) and moderate activity on Pseudomonas aeruginosae, Klebsiella pneumoniae and Proteus mirabilis (Tables 2 and 3). The essential oils from Njoro I, and Njoro II, (all these are areas in one geographical region) showed less activity on almost all the microbes (Table 3 ).

The concentration of the oil were generally in the range of 100 times or more than the standard antibiotic (Chloramphenical), the essential oils were more effective than thestandard antibiotic in view of the content of the active ingredient in the mixture of the oils. The essential oils from all the populations showed activity on both Gram negative and Gram positive bacteria in addition to the fungi (Candida albicans) as shown by their inhibition zones (Table 2). The difference in activity of the essential oils from the different populations could be attributed to variation of the chemical composition of the essential oil of $O$. gratissimum according to geographical distribution (Lemos et al., 2005).

The analysis of the essential oils from the Eastern region (Meru) and coastal region (Mombasa) of Kenya by GC-MS revealed a major compound (68.8\%) and (74.1\%) respectively with a Kovat's index of 1356 (Table 4$)$. Eugenol was the major compound present in the essential oil of this plant. The compound which was identified as eugenol has been reported to present antimicrobial (Nakamura et al. 1999; Iwalokun et al. 2003; Lemos et al. 2005; Matasyoh et al., 2007), insecticidal (Chavan and Nikam, 1982), antihelminthic (Pessoa et al. 2002) and nematicidal (Chatterje et al. 1982) properties. Thus, eugenol is responsible for the activity of the essential oil of this plant.

Different geographical locations have shown different chemical percentages and chemical compositions of this plant. Other reports have shown chemical composition percentages similar or higher than ours (Lemos et al., $2005)$ with eugenol (57.82\%) followed by $\alpha$-bisabolene (17.19\%) and thymol (9.8 \%); (Iwalokun et al., 2001) with essential oil obtained from the seeds of O. gratissimum containing thymol and eugenol in amounts ranging from 32 $\%$ to $65 \%$; (Nakamura et al., 1999) reported eugenol $(67 \%)$ as a major component ; (Keita et al., 2000) reported thymol (46\%) p-cymeme (12\%) and $\gamma$-terpene + trans-sabiene hydrate $(17 \%)$ for O. gratissimum in the Republic of Guinea.

The MIC (Matasyoh et al., 2007) which was done on the EO from Eastern Kenya (Meru) only, showed very good activity and the results were comparable or sometimes better than standard antibiotic.

Meru EO gave the best consistent results in their effectiveness as compared to the other 12 remaining populations (Table 3). Even though the MIC for the Meru oil is greater than that of the standard reference antibiotic, 
it should be realized that the EO comprises of many other compounds and not only eugenol (Table 4). This implies that pure eugenol from O. gratissimum could show higher inhibition than the crude essential oils (Table 2). This was also observed by Lemos et al. (2005).

\section{Conclusion}

This antimicrobial activity of Ocimum gratissimum L. varied from different geographic conditions. The sample from Eastern region (Meru) of Kenya showed very remarkable activity against Gram negative bacteria $(E$. coli, K. pneumoniae, S. typhi, P. mirabilis) and Gram positive bacteria (S. aureus and Bacillus spp). This indicates that this plant can be used as herbal medicine in the management of ailments caused by these microbes.

\section{Acknowledgement}

The authors are thankful to Prof. Uzi Ravid of Newe Yaár Center in Israel for making available the GC-MS apparatus for this work. Mr Nicholas M. Karubiu and Joyce J. Kiplimo for help in the bioassay experiments. Also, the Blin Foundation from Germany, for the sponsorship.

\section{References}

1. Adams, R. P. (1995). Identification of essential oil components by gas chromatographylmas spectroscopy. Carol Stream, USA: Allured Publishing Corp.

2. Adebolu, T. T. and Salau Abiola Oladimeji (2005). Antimicrobial activity of leaf extracts of Ocimum gratissimum on selected diarrhea causing bacteria in Southwestern Nigeria. Afr. J.Biotech. 4(7): 682-684.

3. Chatterje, A., Sukal, N. C., Laskel, S. and Ghoshmajumadar, S. (1982). Nematicides principal from two species of Lamiaceae, J. Nematol. 14:118-120.

4. Chavan, S. R. and Nikam, S. T. (1982). Mosquito larvicidal activity of Ocimum basilicum Linn. India J. Med. Res. 75:220-222.

5. Duffy, C. F. and Power, R. F. (2001). Antioxidant and antimicrobial properties of some Chinese plant extracts. Int J. of Antimicrob. Agents 17:527-529.

6. FAO, Forestry Paper 67 (1986). 'Some Medicinal Forest Plants of Africa and Latin America.'

7. Harjula, H. (1980). Mirau and his practice: A study of the ethnomedicinal repertoire of a Tanzanian herbalist pg 223. Tri-med. books London.

8. Iwalokun, B. A, Gbenle, G. O., Adewole, T. A. and Akinsinde K. A. (2001). Shigellocidal properties of three Nigeria Medicinal Plants: Ocimum gratissimum, Terminalia avicennoides and Mormordia $\quad$ balsamina. J. Health Popul Nutr 19 (4): $331-335$.

9. Iwalokun, B. A., Gbenle, G. O., Adewole, T. A., Smith, S. I., Akinsinde, K. A. and Omonigbehin, E. A. (2003). Effects of Ocimum gratissimum L. essential oil at sub-inhibitory concentration on virulent and multi drug resistant Shigella Strains from Lagos, Nigeria, APMIS., III (4): 477-82.

10. Keita, S. M., Vincent, C., Schmit Jean-Pierre and Belanger, A. (2000). Essential oil Composition of Ocimum basilicum L., O. gratissimum L. and O. suave L. in the Republic of Guinea. Flavour Frag. J. 15:339-341.

11. Kokwaro, J. O. (1993). Medicinal plants of East Africa, East Africa Literature Bureau, Kampala, Nairobi, and Dar-es-Salaam. P. 106-115.

12. Lemos, J. A., Passons, X. S., Fernande, O. F. L., Paula, J. R., Ferri, P. H., Souza, L. K. H., Lemos, A. A. and R. R. M. Silva (2005). Antifungal activity from Ocimum gratissimum L. towards Cryptococcus neoformans. Mem. Inst. Oswaldo Cruz. 100 (1): 55-58.

13. Matasyoh, L. G., Matasyoh, J. C., Wachira, F. N., Kinyua, M. G., Muigai, Thairu A. W. and Mukiama, T. K. (2007). Chemical composition and antimicrobial activity of the essential oil of Ocimum gratissimum L. growing in Eastern Kenya. Afr.J.Biotechnol. 6 (6):760-765.

14. Mshana, N. R., Abbiw, D. K., Addae-Mensah, I., Adjanohoun, E., Ahji, M.R.A., Enow-Orock, E. G., Gbile, Z. O., Naomesi, B. K., Odei, M. A., Adenlami, H., Oteng-Yeboah, A. A., Sarppony, K., Sofowora, A. and Tackie, A. N. (2000).Traditional medicine and pharmacopoeia contribution to the revision of Ethnobotanical and Floristic Studies in Ghana, Scientific, Technical and Research Commission of the Organisation of African Unity.

15. Nakamura, C. V., Nakamura, T. V., Bando, E., Melo, A. F. N., Cortez, D. A. G. and Dias Filho, B.P. (1999). Antibacterial activity of Ocimum gratissimum L. essential oil. Mem. Inst. Oswaldo Cruz., 94: 675-678.

16. NCCLS-National Committee for Clinical Laboratory Standards (1999). Methods for determining Bacterial Activity of Antimicrobial Agents, Wayne, Pa.

17. Pessoa, L. M., Morais, S. M., Bevilaque,C. M. L. and Luciano, J.H.S. (2002). Antihelmintic activity of essential oil of Ocimum gratissimum Linn and eugenol against Heamonchus contortus. Ver. Parasitol. 109:59-63.

18. Watt, J. M. and Breyer-Brandwijk, M.G. (1962). Medicinal and poisonous plants of Southern and Eastern Africa. E\&S. Livingstone, Ltd. London. 